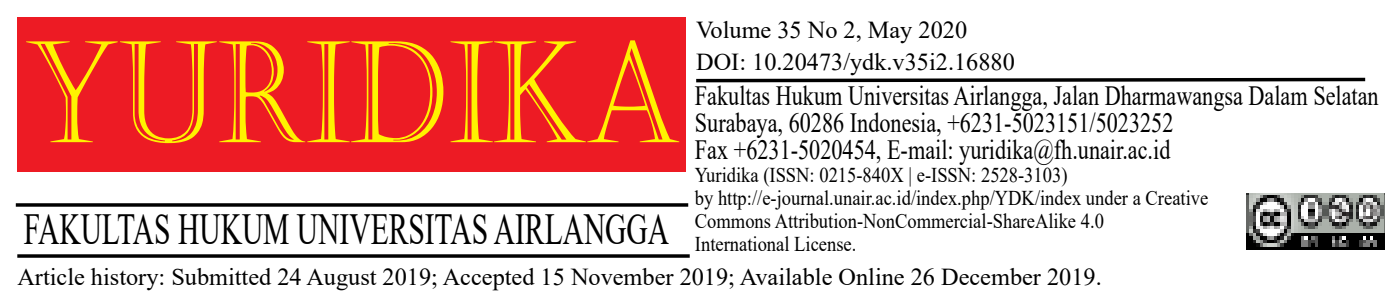

\title{
Insurance Construction Services in Infrastructure Development
}

\author{
Dimas Aulia Azizi \\ dimas.azizi29@gmail.com \\ Narotama University
}

\begin{abstract}
The Construction Services Insurance Agreement has an important role in infrastructure development in Indonesia. The guarantor, in this case, the insurance company provides guarantees in terms of planning up to maintenance. Or before construction up to post-development within a certain period. Insurance agreements made with a variety of considerations, including; protect national interests, avoid contractors who default or have bad intentions, geographical factors in an area, and so forth. But on the other hand, it also to protect the interests of contractors or construction service providers (the insured). For this research, the focus is on the accountability of construction service providers as consumers of insurance companies because construction service providers require insurance companies to transfer some of the risks while carrying out development projects. If in the course of the project an undesirable event occurs starting from the collapse of the building, damage to heavy equipment and so on, which fall within the scope of the object of the insurance agreement, the construction service provider can file a claim against the insurance company to compensate the loss suffered by the construction service provider. Thus it is necessary to analyze the legal relationships and procedures between construction service providers and insurance companies related to infrastructure development. In analyzing and answer the legal issues above, the research methods used are the statute approach (based on applicable laws) and the conceptual approach (based on legal concepts or theories from legal experts).
\end{abstract}

Keywords: Agreement; Insurance; Construction Service.

\section{Introduction}

Indonesia is currently in a major change, both in the social, political, economic, and cultural fields. One of the results of these big changes is related to the political life of the Indonesian people, which shifted from the beginning of the people who lived in the realm of monolithic power, towards a much higher quality 
community life; one of them by doing development in various aspects of life. ${ }^{1}$ To realize good development, one thing that needs to be improved is to improve the quality of construction service providers. Therefore, to maximize the role of Indonesia's construction service providers to become world-class, a thorough and continuous evaluation is needed, not only for the construction company itself but also involving the relevant parties. In its task, the construction service provider organizes and enhances the role of the community to carry out the development of solid and reliable construction services. And a conducive, transparent, efficient business climate, professional ethics, and business ethics is the mission in the construction services. ${ }^{2}$

In the era of President Jokowi's leadership, the State of Indonesia prioritized infrastructure development in the public interest, hence from 12 January 2017 a new law adopted, namely Law No. 2 of 2017 concerning Construction Services, in the future referred to as Law No 2/2017, which replaced the law the old law, namely Law of the Republic of Indonesia Number 18 of 1999 concerning Construction Services which has been deemed incompatible with developments in the current era. The definition of construction services regulated in Article 1 number 3 of Law No. $2 / 2017$, namely "construction work is the whole or part of the activities which include construction, operation, maintenance, demolition, and rebuilding of a building".

Construction work in terms of construction, operation, maintenance, demolition, and rebuilding of a building needs to pay attention to the legal relationships that might arise in these activities. The legal relationship between business operators and construction service providers is outlining in the construction work agreement. In the agreement, the business actor is a service user, while the insurance company is a service provider. In the case that service providers carry out construction projects to ensure that they avoid risks that arise, the service provider requires insurance.

1 Joetata Hadihardaja, 'Membangun Industri Konstruksi Indonesia Menjadi Kelas Dunia' (2005) 13 Media Komunikasi Teknik Sipil.[11].

2 ibid.[13]. 


\section{Construction Services Agreement under Statutory Regulations}

Construction services are actions or activities in the form of services of construction experts in realizing infrastructure development in other physical forms between the owner or user of the service. And those who serve or service providers with certain construction services expertise in transactional form or not. Law Number 2 of 2017 defines construction services as construction consultancy services and construction work in Article 1 number 1 of Law Number 2 of 2017. Construction consultancy is a service in whole or in part of activities that include the review, planning, design, supervision, and management of the construction or building in Article 1 number 2. Compared with Law Number 18 of 1999 defines construction services by dividing three general consulting services, namely planning services, implementation services, and supervision services. So in the latest Law No. 2 of 2017 defines it by dividing in two, namely consulting services and construction work, by outlining the emphasis of consultancy services is the assessment, planning, design, supervision, and management of the construction of a building. So the scope of construction services is not only on planning and supervision, but it will be wider in scope.

In general, the scope of work for construction services based on Article 1 paragraph 2 of Law Number 18 of 1999; construction work is the whole or a part of a series of planning and implementation activities along with supervision that includes an architectural, civil, mechanical, electrical, and environmental layout of each work. Along with its accessories to realize a building or other physical form. While the scope of construction service work in Article 1 paragraph 3 of Law Number 2 of 2017 concerning Construction Services is the whole or part of activities that cover the construction, operation, maintenance, demolition, and rebuilding of a building. There are differences between the two conditions above.

Related to construction agreements (work contracts) there are three stages of construction activities, namely: ${ }^{3}$

${ }^{3}$ Sulistijo Sidarto Mulyo dan Budi Santoso, Proyek Infrastruktur \& Sengketa Konstruksi, Prenadamedia, (pertama, Prenadamedia Group 2018).[14-17]. 


\section{Pre-Construction Stage}

a. Appointment, i.e., when the service user (owner/client) points to the service provider (consultant planner/supervisor/contractor consultant). In the appointment of the results of the auction to government agencies, the appointment preparation meeting (PAM) previously held, in which several things have confirmed, among them: implementation guarantee, insurance, escalation, unbalanced unit price (HS), and willingness to reduce the value of the contract when in case the offer is greater than the foreign debt loan ceiling (PHLN).

b. Performance guarantee or performance bond must generally submit at $10 \%$ of the contract value, no later than 14 (fourteen) days after the appointment. This guarantee is an attachment to the contract documents signed between the parties involved. This guarantee can be withdrawn by the service provider (contractor) if the work performance has reached $100 \%$ or can be exchanged for a new, smaller guarantee under work performance. In addition to this implementation guarantee, there are other types of guarantees, such as advance payment bond guarantees, guarantees for the quality of work, guarantees for building failures, and insurance.

c. Sign a contract, carried out 14 (fourteen days) on a domestic loan construction project (PDN), and 28 (twenty-eight days) on a PDLN. For projects worth more than Rp 50 billion and complex work, the signing is after obtaining the opinion of a contract legal expert or an official handling the legal and procurement fields. In entering into an engagement, the parties use the contract standards issued by the relevant agency whenever possible.

d. Field handover (STL) or site take over (STO), is carried out after the contract is signed, before the issuance of a Work Start Order (SPMK). In this case, an inspection of the State inventory (if a government project) is carried out in the field and outlined in the minutes of the field inspection.

e. Work Order (SPMK) or notice to proceed (NTP), is issued no later than 14 (fourteen) days after signing the contract. The SPMK is signed after there are no problems with the field inspection. Also, the date and time of the commencement of the work stated at the latest.

\section{Construction Stage}

a. Declaration of Commencement of Work (SPMB) or commencement of work (COW), which is made/signed by the service provider, and as the date of the start of the period for the execution of the work. For small and simple contract values, the SPMB compares to the SPMK or the date of the contract signature. After SPMB published, usually at the request of the service user, a committee formed consisting of elements of the project, planning, implementation, and who control the contract administration in charge of examining everything related to contract changes. This committee will provide recommendations if there are changes to the contract, and make minutes of the results of the contract research. 
b. Field Preparatory Meeting (RPL), or pre-construction meeting (PCM), is a meeting between service users (project leaders) and service providers (contractors, planning consultants, and supervisory consultants). It will be carrying out no later than 14 (fourteen) days after the issuance of SPMK. This meeting intended to convey an understanding of the entire contents of the contract documents, as well as make agreements on matters that are not yet contained in the contract documents and find a solution.

c. The first handover or professional hand over (PHO) will be carrying out when the service provider has completed $100 \%$ of his work under contract documents and work plans based on Curves. First Handover Minutes are made by the service provider and approved by the service user.

d. Maintenance period or retention period, i.e., the period during which the service provider is still responsible for the maintenance and improvement of the results of his work. The maintenance period is usually for 40 days or three months, according to the contents of the contract agreement.

e. The Second Handover or final hand over (FHO) conducted after the maintenance period ends, with the Second Handover Minutes that are agreed by both parties. Service providers are required to submit drawings as a result of the construction (as-build drawings) in full. After this, the contract period has expired, and the building of the results of the project is the full responsibility of the service user.

\section{Post-Construction Stage}

At this stage, the building failure period is covered, namely in which the condition of the building of the project results, which after being handed over by the service provider to the service user, becomes partially or completely and not under the provisions contained in the construction work contract. Or its utilization, which deviates as a result of the fault of the service provider and service user. The coverage period is no more than 10 (ten) years. Regarding building, failure has been regulated through Law Number 2 of 2017 concerning Construction Services and Regulations Government Number 29 of 2000 concerning Construction Services, as well as other laws and regulations related to related fields. Construction agreements (employment contracts) have forms and models in construction agreements, among others. ${ }^{4}$

\section{Government Version}

Usually, every ministry or other state institution has its own "standard." The

$4 \quad$ ibid. $[18]$ 
standard that usually used is the standard of the ministry of public works, and in fact, they have more than one because each directorate-general has its standards.

\section{National Private Version}

In the national private version, it varies according to the tastes of service users (project owners). Sometimes it quotes ministries' standards or those that have advanced to quote (standards) foreign contract systems. However, because it cannot be taken maximally, the national private contract system is less effective and very vulnerable to disputes.

\section{Foreign Private Version/Standard}

Generally, service users (foreign project owners) use contracts with the FIDIC (Federation Internationale Des Ingeniurs Counsels) system or JTC (Joint Contract Tribunals).

In the construction contract (work contract), generally made separately under the stages in construction work, but in the case of integrated work, the agreement can be outlined in one work contract. In general, the work contract is divided into three parts, namely, for planning work, supervision work, and implementation work.

\section{Context of Insurance Agreement in Construction Services}

An insurance company is a company that provides services in mitigating the risk of loss, loss of benefits, and legal liability to third parties arising from uncertain events. The government owns insurance companies themselves, and some are privately owned. According to Law Number 40 of 2014 in Article 1, number 1, stated that insurance is an agreement between two parties, namely the insurance company (the Insurer) and the policyholder (the Insured), which is the basis for receiving premiums by the insurance company in return for:

a. Provide compensation to the insured or policyholder due to loss, damage, costs incurred, lost profits, or legal liability to third parties that may be suffered by the insured or policyholder due to an uncertain event;

b. Give payments based on the death of the insured or payments based on the life of the insured with benefits that have determined and based on the results of 
fund management. ${ }^{5}$

Therefore the purpose of insurance is:

a. Risk Transfer

Risk transfer is the charge in the purpose of insurance, according to the theory of risk transfer, the insured is aware that the threat of harm to his property or life. If his wealth or life threatened, he would suffer loss or loss of life or physical disability. In reducing or eliminating the risk burden, the insured party tries to find a way if other parties are willing to take over the burden of the risk of danger. And he can pay an achievement contract called a premium. The insured holds insurance intending to transfer risks that threaten his assets, losses or lives. By paying a premium to the insurance company (guarantor) since then, the risk goes to the insurer. ${ }^{6}$

\section{b. Compensation Payment}

In practice, the danger that does not always last will truly occur. It is an opportunity for the insurer to collect premiums from the insured, who binds themselves to the insurance company. If at any time the event occurs, which causes losses, then the insured will be paid compensation in proportion to the amount of insurance. Thus, the insured holds insurance that aims to obtain payment for compensation he suffered. ${ }^{7}$

Based on Article 1 number 5 of Law Number 40 Year 2014 concerning Insurance, general insurance is a guarantor who provides compensation to the insured or policyholder due to loss, damage, costs incurred, loss of profits, or legal liability to third parties that may be suffered by the insured or policyholder due to an uncertain event. Based on this article it can be seen that the implementation of insurance is to provide coverage or compensation for all losses arising on the object of insurance.

\footnotetext{
5 Andika Wijaya and Wilda Peace Ananta, Hukum Bisnis Properti Di Indonesia (Gramedia Widiasarana Indonesia 2017).[430].

6 Hilda Yunita Sabrie and Rizky Amalia, 'Karakteristik Hubungan Hukum Dalam Asuransi Jasaraharja Terhadap Klaim Korban Kecelakaan Angkutan Umum' (2015) 30 Yuridika <https://ejournal.unair.ac.id/YDK/article/view/1949/1448>.[391].

7 Wahyu Wardana, 'Hukum Asuransi: Proteksi Kecelakaan Transportasi' (Landasan Toeri, 2009).[15].
} 


\section{Objects in Construction Services Insurance}

In the Contractor, All Risk Insurance can be interpreted as a form of loss protection or to protect an uncertain event in a construction service project. In this form the construction service (the insured) pays the insurance premium to the All Risk Insurance Contractor company (Insurer) and in exchange for the relevant construction services will be provided with a form of compensation in the event of an uncertain event in the before and after the development process. The risk of interests in construction services will be protected or protected by insurance companies. The objects that can be insured by the All Risk Contractor Insurance are: ${ }^{8}$

a. Contract Work is a contract of work including initial work, temporary buildings, material stocks and usually, includes tax (VAT);

b. Material or materials provided by the principal or owner;

c. Heavy equipment or machinery was supporting work (Construction Plant and Equipment or Machinery);

d. Clearance of debris.

The object of the agreement in construction service insurance is different from the object of other insurance agreements. It is because the object in construction services insurance has various activity sectors. So that the object of insurance will certainly be different, an example is the road infrastructure construction services that will be insured is related to the highway. Likewise, if the construction carried out is in the form of a building/apartment, then what will become the object are matters relating to the construction of buildings and apartments.

\section{Premiums on Construction Services Insurance}

The low contribution of the insurance industry to the economy implies that the prospect of this industry is still very large. Gross premiums continue to increase with an average growth above $20 \%$ per year. ${ }^{9}$

One of the characteristics of insurance agreements is consensual. It means

\footnotetext{
${ }^{8}$ Ahliasuransi, ‘Asuransi Contractor' All Risk (CAR)' (Ahliasuransi, 2018) <https://ahliasuransi.com/asuransi-contractors'-all-risks-car/> accessed 10 April 2018.

9 Firdaus Djaelani,[et.,al.] 'Pertumbuhan Industri Asuransi Jiwa Di Indonesia: Suatu Kajian Dari Sisi Penawaran’ (2011) 1 Jurnal Kawistara < https://jurnal.ugm.ac.id/kawistara/article/ view/3925>.[258].
} 
that since the agreement occurs, the insurance agreement will begin to take place, besides that since the agreement will arise rights and obligations by the parties. In this case, the guarantor should compensate if there is a risk, while the main obligation of the insured is to pay a premium.

According to Article 1 number 29 of Law Number 40 Year 2014 it is explained that the premium is an amount of money determined by the insurance company (the guarantor) and approved by the policyholder (the insured) to be paid based on the insurance agreement or an amount of money determined under the provisions of the legislation which underlies the insurance program to obtain benefits.

In all risk, contractor insurance explained that the property that can be insured includes: ${ }^{10}$

a. Contract of work: all types of construction service work such as construction work on buildings, roads, railways, structures of bridges, tunnels, dams, sluice gates, ports, shipyards, airports, or underground plazas;

b. Construction planning and equipment;

c. Construction machinery;

d. Costs arising from cleaning up debris, due to an accident;

e. Legal liability arising from damage to property or bodily injury to third parties and occurs in connection with the process of installation work, in or around the installation area.

The price of the insurance agreement is the basis for calculating the premium and the maximum compensation limit. ${ }^{11}$ The all-risk contractor policy starts in effect from the start of work or after being unloaded at the location and ends with the portion of the work contract that has been hand over or used plus the maintenance period. ${ }^{12}$

Related to the value of premiums in construction services is certainly different from insurance in general. The price of premiums on construction services will be much higher compared to the price of general insurance. This is because the risks

${ }^{10}$ Msig, 'Asuransi Konstruksi (CAR) Melindungi Pekerjaan Konstruksi Dari Dasar Hingga Selesai Dibangun' (Msig, 2018) < https://www.msig.co.id/id/asuransi-konstruksi> accessed 10 April 2018.

11 Wanda Agustiranda,[et.,al.] 'Pengaruh Pendapatan Premi, Pembayaran Klaim, Dan Risk Based Capital Terhadap Pertumbuhan Laba Pada Perusahaan Asuransi Yang Terdaftar Di Bursa Efek Indonesia' (2019) 16 Jembatan : Jurnal Ilmiah Manajemen <https://ejournal.unsri.ac.id/index.php/ jembatan/article/view/9220>.[3].

12 Ahliasuransi (n 8). 
faced by construction service providers when carrying out their work are very high. It has become one of the important factors of insurance in construction services.

\section{Policy on Construction Services Insurance}

According to the provisions of Article 255 of the Indonesian Criminal Code, insurance agreements must be made in writing in a deed called a policy. This policy serves as written evidence that an insurance agreement has occurred between the guarantor (the All Risk Contractor Insurance Company) and the insured (Construction Services). The policy states the terms and conditions under the agreed insurance agreement between the two insurers and the insured. Furthermore, Article 257 of the Criminal Procedure Code explains that "insurance agreements are issued immediately closed; the rights and obligations of reciprocity to the guarantor and the insured come into force from then on, even before the policy is signed. The closing of the agreement issues an obligation for the guarantor to sign the policy within the specified time and submit to the insured".

In this all risk contractor insurance policy the things that are regulated or included in the minimum are as follows: ${ }^{13}$

1. General Exceptions;

2. Guarantee Period;

3. General condition;

4. Part I - Material Damage;

5. Special Exclusions for Part I;

6. Assured Property;

7. Basis of Settlement of Losses;

8. Expansion of Collateral;

9. Part II - Responsibility For Third Parties;

10. Special Exclusions for Part II;

11. Special Conditions Apply to Part II.

The description above is a form of insurance policy for all contractor risks compiled by insurance companies for construction services. Where, although the

13 Axa-mandiri, 'Polis Asuransi Contractor All Risk (CAR Insurance)' (Axa-mandiri, 2018)<https://www.axa-mandiri.co.id/wp-content/uploads/2014/04/Polis-Asuransi-Kontraktor-Semua-Risiko-Contractor-All-Risk-CAR.pdf > accessed 10 April 2018. 
existence of the policy is not an absolute requirement for an insurance agreement; that the Insurance agreement takes effect at the time of the agreement, but with the policy, the Insured has a "proof" related to participation in the insurance program.

\section{Legal Relationship in the Construction Services Insurance Agreement}

In general, the parties in the insurance agreement are the Insurer (Insurance company) and the Insured (construction service provider). In the series of construction service processes involving many parties, such as the government, the executors, and the people who are interested in the construction of the construction. But in the management of construction projects globally there are five main groups (parties) involved, namely: ${ }^{14}$

1. Clients can be individuals, government agencies or private companies. For individuals, for example, the person wants to build a house, as well as to a private institution or company that wants to build a building. These clients are essentially those who need a result, have the authority (as well as money) to order and approve it.

2. Users are those who will operate and maintain the facilities that have been built and provided. In many cases, the user is the most important party, but most often ignored, it may be that the same organization is both a client and a user, but the people involved may be different.

3. The designer (designer) which usually consists of architects and experts who are responsible for bringing the client's needs into reality. In a building project, architects do play the biggest role, but architects also need the support of many parties such as draftsmen, civil engineers, mechanical, electrical, and others.

4. The executor here is better known as a contractor (builder), which can be a government contractor (private) or a private contractor. Contractors are those who carry out physical construction work, and sometimes clients can also order special equipment/materials not through the contractor, but rather directly to the supplier (supplier). The suppliers must keep in good coordination with the contractor so that that project completion can go well.

5. The authorities, in this case, are usually the government or the city government that sets regulations/laws, requirements and certain standards regarding construction and work safety. With these provisions or provisions can have a major effect on the shape of buildings and facilities provided.

14 ibid.[11-12]. 


\section{Claim Mechanisms Regarding Construction Services}

By definition, a claim can be interpreted as an act of someone to ask for something, where someone's rights have been lost before because he thinks he has the right to get it back. ${ }^{15}$ In a construction project that involves many parties with their respective rights and responsibilities, claims problems can arise.

In this case, there are four kinds of categories of climate namely:

a. Claims by service providers (consultants/contractors) to service users (owners), in the form of being paid late, not being paid, late for field surrender, design changes, acceleration of work completion time, the government was resulting in additional costs.

b. Claims by service users (owners) to service providers (consultants/contractors), in the form of quality of work that is not according to specifications, unable to complete work according to contract, cannot submit work results.

c. Claims by sub-service providers or material suppliers to the main service providers (main contractors), in the form of late payment, not paid.

d. Claims by service users (owners) and service providers (consultants/contractors) to insurance institutions, in the form of pre-implementation guarantees (bid guarantees, down payment guarantees, implementation guarantees, preservation guarantees), insurance in implementation (job insurance, third party insurance, labor insurance), insurance after implementation (professional liability insurance, professional indemnity insurance)

e. Claims by the community to service users (owners and service providers (consultants/contractors), in the form of compensation requests, claims due to the implementation of development projects that affect the social, economic, and environmental lives of the local community. ${ }^{16}$

In this case, construction services as service users and insurance companies as service providers, construction services as consumers of insurance companies that will claim their rights in the event of an object due to uncertain events suffered by construction service providers or service users. Then the insurance company must fulfill the rights of the consumer, that is to replace the object due to an uncertain event under the agreement agreed between the two parties. The main causes of claims include:

1. Incorrect design information (delayed design information);

2. Imperfect design information (inadequate design information);

\footnotetext{
15 Sulistijo Sidarto Mulyo dan Budi Santoso (n 3).[79].

16 ibid.[80].
} 
3. Inadequate site investigations;

4. Slow client response (slow client response);

5. Poor communication (poor communications);

6. Unrealistic time targets;

7. Imperfect contract administration (inadequate internal events);

8. Uncontrollable external events (uncontrollable external events);

9. Incomplete tender information (incomplete tender information);

10. Unclear risk allocation (unclear risk allocation); and

11. Late payment (lateness-non payment).

Thus, construction claims can occur due to causes that come from service users and service providers, or other causes beyond the control of these parties. Service users or service providers are equally entitled to file/claim claims.

\section{Conclusion}

Characteristics of a construction services insurance agreement that insurance is an additional agreement from the main agreement transfer some of the risk of construction services to the insurance company if there is a loss caused by uncertain risks such as building collapse, delays in the term of project construction, providing incorrect information guaranteed to construction service insurance policy. The object of the agreement in the construction service insurance is different from the object of the other insurance agreement, for example, in the case of road construction services, what will be insured is related to the highway.

The mechanism in submitting a claim that is the insured (construction service provider) submits a claim to the guarantor (insurance company) by showing the evidence when damage occurs that included in the object agreed in the contents of the insurance policy. An insurance agreement to protect the interests of the insured (construction services), while safeguarding the interests of the client (owner) so that the construction services insurance agreement as the main agreement can be implemented properly. 


\section{Bibliography}

Ahliasuransi, 'Asuransi Contractor' All Risk (CAR)' (Ahliasuransi, 2018) $<$ https:// ahliasuransi.com/asuransi-contractors'-all-risks-car/> accessed 10 April 2018.

Andika Wijaya and Wilda Peace Ananta, Hukum Bisnis Properti Di Indonesia (Gramedia Widiasarana Indonesia 2017).

Axa-mandiri, 'Polis Asuransi Contractor All Risk (CAR Insurance)' (Axamandiri, 2018)<https://www.axa-mandiri.co.id/wp-content/uploads/2014/04/ Polis-Asuransi-Kontraktor-Semua-Risiko-Contractor-All-Risk-CAR.pdf> accessed 10 April 2018.

Firdaus Djaelani, 'Pertumbuhan Industri Asuransi Jiwa Di Indonesia: Suatu Kajian Dari Sisi Penawaran' (2011) 1 Jurnal Kawistara <https://jurnal.ugm.ac.id/ kawistara/article/view/3925>.

Hilda Yunita Sabrie and Rizky Amalia, 'Karakteristik Hubungan Hukum Dalam Asuransi Jasaraharja Terhadap Klaim Korban Kecelakaan Angkutan Umum' (2015) 30 Yuridika <https://e-journal.unair.ac.id/YDK/article/ view/1949/1448>.

Joetata Hadihardaja, [et.,al.] 'Membangun Industri Konstruksi Indonesia Menjadi Kelas Dunia’ (2005) 13 Media Komunikasi Teknik Sipil.

Msig, 'Asuransi Konstruksi (CAR) Melindungi Pekerjaan Konstruksi Dari Dasar Hingga Selesai Dibangun' (Msig, 2018) <https://www.msig.co.id/id/asuransikonstruksi $>$ accessed 10 April 2018.

Sulistijo Sidarto Mulyo dan Budi Santoso, Proyek Infrastruktur \& Sengketa Konstruksi, Prenadamedia, (pertama, Prenadamedia Group 2018).

Wahyu Wardana, 'Hukum Asuransi: Proteksi Kecelakaan Transportasi' (Landasan Toeri, 2009).

Wanda Agustiranda, [et., al.] 'Pengaruh Pendapatan Premi, Pembayaran Klaim, Dan Risk Based Capital Terhadap Pertumbuhan Laba Pada Perusahaan Asuransi Yang Terdaftar Di Bursa Efek Indonesia' (2019) 16 Jembatan : Jurnal Ilmiah Manajemen <https://ejournal.unsri.ac.id/index.php/jembatan/ article/view/9220> 